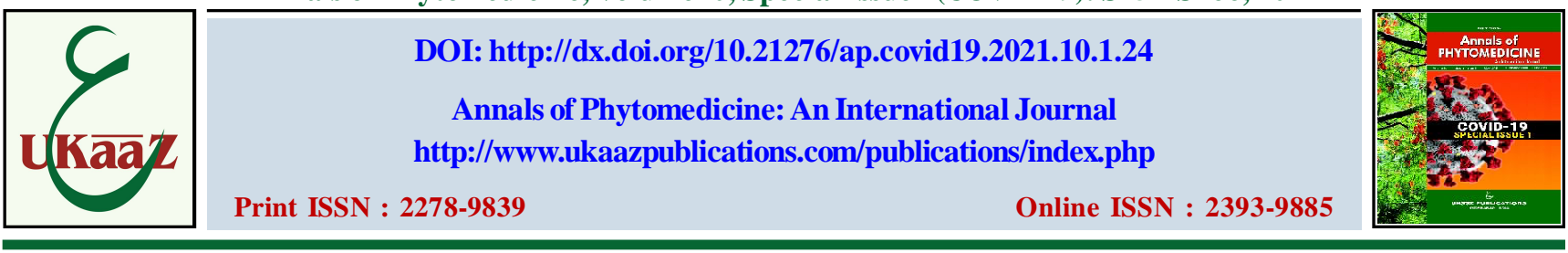

\title{
Healthcare management through mitigation of COVID-19 pandemic with leafy vegetables
}

\author{
A.K. Abdussalam*, P.K. Prajith*, P.V. Jyothi*, K.P. Prasanth***, A.P. Anu****, K. Azeez ${ }^{* * * * *}$ and M.K. Ratheesh Narayanan****** \\ Department of Botany, Sir Syed College, Taliparamba-670142, Kannur, Kerala, India \\ * Department of Botany, Nehru Arts and Science College, Kanhangad-671314, Kasaragod, Kerala, India \\ ** Department of Botany, M.E.S.Ponnani College, Ponnani-679586, Malappuram, Kerala, India \\ *** Department of Botany, S.N. College, Thottada-670007, Kannur, Kerala, India \\ **** Department of Sanskrit, Nehru Arts and Science College, Kanhangad-671314, Kasaragod, Kerala, India \\ ***** PSMO College, Malappuram, Tirurangadi-676306, Kerala, India \\ *****Department of Botany, Payyanur College, Edat-670 327, Kannur, Kerala, India
}

\section{Article Info}

Article history

Received 5 May 2021

Revised 21 June 2021

Accepted 22 June 2021

Published Online 30 June 2021

\section{Keywords}

COVID-19

Leafy vegetables

Nutritional factors

Vitamins

Minerals

Antioxidants

\begin{abstract}
COVID-19 pandemic becomes one of the leading challenges across the world. To fight against the virus, compulsory maintenance of nutritional status is very important. Age, sex, health status, medications and lifestyles are the important factors affecting individuals regarding their nutritional status. Due to the COVID19 pandemic, the nutritional status of individuals is destabilized. To survive the current situation, a sustainable nutritional dietary should be maintained for strengthening the immune system. One of the most important ways to maintain the immune system is to supplement enough vitamin C. A spectrum of viruses that belongs to the coronavirus in humans usually causes the common cold, which is recently severe acute respiratory syndrome (SARS). SARS considered a major threat to public health, which is an emerging infectious disease. According to WHO, COVID-19 caused by the coronavirus, in which most people probably have low immunity. Eighty-five per cent of the immune system has been made by plant-based food supplements, which increase beneficial intestinal bacteria. Minerals like zinc, magnesium, micronutrients, herbal foods and vitamins C, D and E and plenty of water promote health, which is highly helpful to overcome the infection. Many studies revealed that COVID-19 infection prevented by the powerful antioxidant glutathione and bioflavonoid quercetin; to control COVID-19, plant-based foods playing a very important role to increase the immunity of people. Leafy greens and vegetables play a very important role in food and nutritional safety. Green leafy vegetables are an excellent source of vitamins, phenolic compounds and minerals. Calcium and iron are rich in leafy vegetables than that of staple food grains. Folic acid is also present in leafy vegetables. Different leafy greens, especially Moringa oleifera leaves, contain a high amount of folic acid compared to other leafy and non-leafy vegetable plants. This review paper aims to explore the nutritional and antinutritional factors of some important leafy vegetables. The content of nutritional and antinutritional factors varies among the genera and species of most of the edible leafy vegetables. Antinutritional factors are considered the important compound in the plant, in which they determine the absorption capacity of nutrients in human beings. Important dietary factors such as phytates, oxalates, nitrates, glycosides and cyanogenic are fruitful in many health-related problems. This article mainly explores the significance of nutrition and the use of leafy vegetables to boost up the immunity system in human beings and provide reliable dietary strategies about food safety and nutrition to survive COVID-19 pandemic around the world, especially in India.
\end{abstract}

\section{Introduction}

The COVID-19 disease attacked the people with a low immune system, in which people were coming under overages. Due to the inadequate responses of the immune system, it will be an open invitation for different diseases, mainly heart disease, diabetes, cancer, etc. To increase the body's immune system, plant-based food support and help intestinal beneficial bacteria and the gut microbiome (Casanova, 2006; Chen et al., 2020). Corona patients need plenty of water which will help to keep their mucous membrane

Corresponding author: Dr. A.K. Abdussalam
Assistant Professor, Department of Botany, Sir Syed College,
Taliparamba, Kannur-670142, Kerala, India
E-mail: salamkoduvally@gmail.com
Tel.: +91-9847654285

Copyright $\odot 2021$ Ukaaz Publications. All rights reserved.

Email: ukaaz@yahoo.com; Website: www.ukaazpublications.com moist, which help to lower the chances of affecting flue and cold. Natural preparations like coconut water, homemade fruit juice, green tea are helpful to sense thirst and smell. The morphological and chemical composition of the COVID-19 virus is similar to human surrogate coronaviruses (Liang, 2020; Chen et al., 2020). Data are available to both sustainability in the environment and effective coagulation methods regarding the COVID-19 pandemic (Baudoin and Fresco, 2002; Aguilar et al., 2017; Ahern et al., 2020; WHO, 2020). World Health Organisation (WHO) and CDC (Centers for Disease Control) states that elderly people having health probles, especially diabetes, lung disease and heart disease are more succeptable to COVID-19 disease. Such people are very difficult to fight against this deasese. Precautions must be taken youth and healthy individuals since this disease is easy to spread. Important symptoms of COVID-19 disease are cough, breath and brevity. Proper nutrition and hydration are vitally important in this 
condition. Well balanced diet has lower risk for chronic illness and pandemic diseases. Each people diet should contain variety of fresh vegetables for getting the fibre, minerals, protin, antioxidants and vitamins. Proper hydration with the help of pure water is compulsory. Quick boost of immunity system is an important need in this hour for keeping the body fit.

\subsection{Lifestyle and diseases}

The immune system always alters due to the influence of different stress present in the body (Dias, 2012). Sleeping influences the immune system of the body and will make an opportunity to heal certain critical illness (Aletor et al., 2002; Alexander et al., 2008; Colonna et al., 2016). Normal body exercise also helps to raise the white blood cell levels and antibiotics, which may fight against various infections (Join and Calendar, 2020). Critical illness can alter due to exercises that always strengthen the muscle mass. (Grusak and Penna, 1995). Studies revealed that exercise could help to prevent blood coats, which is one of the normal symptoms found during the COVID-19 disease (Jenkins et al., 2001). Well balanced dieting is very important to maintain health and also avoid junk food. Due to unbalanced and unmatched dieting made different health problem and that always affected the immune system too. Frozen or fermented food is producing different seasonal diseases (Britton, 1966; Gupta and Haslam, 1980; Harland and Oberleas, 1987; Fann and Kaneene, 1993; Louisce and Wilfried, 2004; Bauala and Barthet, 2007; Mepba et al., 2007).

\subsection{Role of micronutrients against diseases}

Micronutrients are essential in the synthesis of DNA and cell proliferation (Fuhrman, 2020), which is important in the regulation of unusual and adaptive immune reactions, cell signalling and immune cells production (Freudenberg, 1962; Gopalan et al., 2000; Champ, 2002; Chai and Liebman, 2005). Each and every micronutrients are playing very important role against dieseaes and body immunity. Of the micronutrients, magnesium plays a very important role in strengthening the immune system's especially lymphocytes and natural killer cells. Micronutrients are a key source of energy for the synthesis of adenosine triphosphate (ATP), which is popularly called the cell's energy currency. Without their presence, the cell cannot function properly. Oxygen delivery from our lungs to the entire human body is controlled by haemoglobin in the blood. The micronutrient such as magnesium helping haemoglobin for this doing the same function. Oxygen is very important as far as COVID-19 infection is concerned, which attacks the respiratory system (Kalogeropoulos et al., 2010). Magnesium is rich in food such as chocolate, black beans, whole grain and avocados (Jenkins et al., 2001; Gupta et al., 2015; Yang et al., 2015).

\subsection{Vitamines rich foods and health}

Vitamins are most important organic compounds in which each and every people needs it in small quanties. Vitamins are mainly supplement from the food. Organisms have different vitamin requirements as far as their body is concerned. Mostly human being gets their vitamin $\mathrm{C}$ from their diets. Microbial infection always reducing vitamin D and related mechanisms. Vitamin D is not aviliable from food. Body normally synthesis vitamins when they are exposed to sunlight. The metabolism and activities of vitamin D are well documented (Uusiku et al., 2010; Sallard et al., 2020; Calder, 2020). The innate immune system develops in the
COVID-19 patients, responsible for developing pro-inflammatory and anti-inflammatory cytokines responses to bacterial and viral infection diseases. Vitamin D is an effective immunity modulator; $1,25(\mathrm{OH}) 2 \mathrm{D} 3$ stimulates responses induced by the T-helper type of cell 1 (Th1), primarily by trying to suppress inflammatory cytokine production IL-2 and interferon-gamma (INF $\pi$ ). Continuous usage of pharmaceutical drugs always increases age. Vitamin D supplementation improves the antioxidant production and related genes (glutathione reductase and subunit controller glutamatecysteine ligase). Many vegetables like bell peppers, spinach, cauliflower, eggplant are better known to be rich in vitamin $\mathrm{C}$ and support immunity. Vegetables like mushrooms, broccoli, and even kale are considered immunity boosters. Such vegetables can include in the diet. Super foods like spirulin and curcumin are rich in vitamin $\mathrm{C}$ and minerals. Older adults should consume this food, which will help to build and strengthen the immunity at a higher level. The health of older adults is normally maintained by vitamin $\mathrm{E}$, a powerful antioxidant that can protect ours from various infections caused by virus and bacteria. Sunflower seeds, peanut butter and soaked almonds should consume for getting the vitamin E. Vitamin $\mathrm{C}$ influencing oxidative stress and immune abnormalities. Generation of reactive oxygen species (ROS) and antioxidant position are linked with the immunity system. Vitamin $\mathrm{C}$ provides antioxidant protection as a radical scavenger of the peroxyl and oxygen aqueous phase.

\subsection{Antioxidants and immunity}

Antioxidants are playing very important role in immunity. They are found in some foods and prevents damages caused by free radicals. Glutathione is considered the most powerful antioxidant in the body. Normal diet contain naturally availiable antioxidant compounds which normally synthesise and stabilize reactive harmful molecules known as free radicals. These radicals are generated in normall cellular metabolism. Glutathione scavenges damaging free radicals, which helps repair the tissues and involves building the chemicals and proteins, which support the immune system. Glutathione production is promoted by $\mathrm{N}$ acetylcysteine, which is popularly called NAC (Kumari et al., 2004). Most of the vegetables and fruits contain bioflavonoid, namely; quercetin, which inhibits the infection of COVID-19 attack. Quercetin always supports antioxidant capacity and guards lung tissue (Odhav et al., 2007). The major sources of quercetin are leafy green vegetables, grapes, fennel leaf, red onion, oregano, chilli pepper dill, peppers, apples, green tea, and black tea (Price and Butler, 1978; Oboh, 2005).

\section{Role of leafy greens/vegetables in immunity}

Wild leaves are among the most widely consumed wild foods. Wild food plants are locally mentioned and classified as 'weeds,' sprouting and which are flourishing after rains (Gupta and Haslam, 1980; Kamalu, 1993; Jenkins et al., 2004; Kala and Prakash, 2004; Odhav et al., 2007; Radek and Savage, 2008). Women use them in soups, stews and relish that add flavour to staples. While some leaves are high in fats, others are high in protein, and most are a good source of vitamins and minerals. Among the four socio-cultural groups studied, wild and weedy greens form the most regularly used food supplement in the three tribal groups and are of great dietary importance among the tribal communities of northern Kerala, especially Wayanad district. There are sixty wild edible greens, but only a few species are widely used. For instance, the women and children of Paniya community regularly collect only eight species 
of wild edibles. The Kuruma and the Kattunaikka tribes zero in on just four such species regularly, and others often make do with just three types of wild edible leaves (Table). The detailed household survey conducted among the tribal communites revealed that the Paniya families consume about 43 species, followed by the Kattunaikka, who consume 37 species. The Kuruma consume about 21 types of wild edible leaves and the settlers restrict themselves to between 8 and 14 types of leafy greens. Most of these species are herbs (90\%), and very few are shrubs. It was found that women play a key role in the collection and processing of wild edible greens. As food providers for the family, they alone, by and large, continue to possess the knowledge related to its usage. An analysis of dependency on various landscapes for collecting these plants (Figures) shows that wayside and open areas provide the maximum species (28), followed by thickets and forest (20 species), paddy fields and associated ecosystems. Generally, vegetables are widely designated as "protective foods" in the human diet due to their varied health benefits attributable to the richness in vitamins, essential fatty acids, minerals, amino acids, dietary fibre, and various essential bioactive compounds. These include health-promoting plant secondary metabolites composed of antioxidants and phenolic compounds. It is well acknowledged that to meet recommended daily allowance of nutrition, the World Health Organization (WHO) recommendation at least $400 \mathrm{~g}$ of fruit and non-starchy vegetables (WHO) is used. Recommendations from Americans dietry guidelines revealed that, five servings of vegetables per day based on an intake of two thousand calories (HHS/USDA, 2015). It is also recommended that one of the five servings of vegetables should be green leafy vegetables. Nutritionists and dieticians are of the opinion that people should diversify their diets as no single vegetable meets all the nutritional requirements necessary for good health and wellbeing. Hence, in today's agri-food systems, more emphasis is given to crop diversification to fulfil human nutritional requirements and reducing the pressure on cereal production (Ramulu et al., 2003; Susin et al., 2006; Tamme et al., 2010; Santos et al., 2012; Shukla et al., 2016). Globally, crop diversity and nutritional value of vegetable crops are of special significance for improving food and nutrition security.

Different types of bioactive compounds are present in the plants and which are considered as the major sources of phytochemicals and synthesis of biomolecules, which are reported to be key to good health. Researchers have shown that the composition of phytochemicals is very distinctive and varies widely amongst plants. For instance, vegetables that belong to the Alliaceae family (e.g., onions, garlic, shallots, leek, welsh onion and chives) are characterized by thiosulfides and flavonoids. Cruciferous, vegetables that belong to the Brassicaceae family (e.g., cabbage, cauliflower, kale and broccoli) contain high sources of glucos inolates, and those that belong to the Cucurbitaceae family (e.g., squash, pumpkin, cucumber, melon and bitter gourd) are rich in carotenoids and tocopherols. However, the compositions of these phytochemicals have been documented to be affected by factors such as genotypic characteristics, climatic conditions, edaphic factors and management practices. For instance, it was shown that for the same plant species, the mineral nutrients content and total phenolic compounds and antioxidants could be altered by applying different sources of nutrients (Onyesom and Okoh, 2006; Torres et al., 2014).
It is worth noting that while there are many groups of chemical compounds that have health benefits, others can be very toxic and fatal to humans when consumed as such. Phytochemicals can be broadly classified as nutritional (e.g., essential fatty acids, proteins, vitamins, minerals and phenolic compounds) and antinutritional (e.g., oxalates, tannins, nitrate) chemical compounds. Consumers and researchers need to understand the importance of these chemicals and their impacts on human health and available methods for their assessments. This paper aims at reviewing the common phytochemicals in green leafy vegetables grown in various geographic locations of the world. Several nutritional factors are considered as the health-promoting phytochemicals in some cases which are act as the health-inhibiting, or toxic phytochemicals and it is referred to as antinutritional factors. The importance of the sephyto chemicals will be highlighted to reflect their beneficial or toxicity and inhibitory effects on human health and wellbeing. Additionally, a brief description will be made on methods for determining the compositions of these phytochemicals in green leafy vegetables.

\subsection{Leafy greens of Northern Kerala}

Northern Kerala is hallowed with rich biodiversity due to the occurrence of weird geographic factors, comprising four districts; Kozhikkode, Kannur, Wayanad and Kasaragod. These districts have different biodiversity hotspot regions with different endemic flora, home to diversified medicinal plants, crop species and leafy vegetables. Out of four districts, Wayanad is blessed with different ethnic communities; they consume different types of wild leafy vegetables, which are endemic to such area as a regular food supplement. Leafy vegetables are a rich sources of many essential nutrients and form an important category of vegetable groups that may be considered antiageing wonders. Numerous types of wild vegetables are exploited, and they are used as an important source of food; they provide an adequate level of nutrition. Common people of Northern Kerala are widely consuming leaves of different leafy vegetables. Sixty different types of leafy greens are documented (Table) as they are: Aerva lanata, Alternanthera sessilis, Amaranthus polygonoides, A. spinosus, A.viridis, Amorphophallus commutatus, A. paeoniifolius, Artocarpus heterophyllus, Asystasia gangetica, Bacopa monnieri, Basella alba, Benincas apruriensf. hispida, Beta vulgaris, Boerhavia diffusa, Cardiospermum halicacabum, Centella asiatica, Chenopodium album, Chenopodium album, Cichorium intybus, Cissus quadrangularis, Clerodendrum serratum, Cnidoscolus aconitifolius, Coccinia grandis, Colocasia esculenta, Commenlina benghalensis, Cucurbita moschata, Cyanotis cristata, Daucus carota sub sp. sativus, Diplazium esculentum, Eclipta alba, Eryngium foetidum, Erythrina variegate, Hibisucss abdariffa, Ipomea aquatic, Ipomea batatas, Leucas zeylanica, Limnophila repens, Momordica charantia, Moringa oleifera, Murraya koenigii, Oxalis corniculata, Passiflora edulis, Peperomia pellucida, Piper betel, Pisonia alba, Plectrantus amboinicus, Portulaca oleracea, Pouzolzia zeylanica, Premna serratifolia, Raphanuss ativus, Sauropus androgynous, Sennatora, Sesbania grandiflora, Solanum nigrum, S. tribatum, Talinum fruticosum, Tamarindus indica, Tinospora cordifolia, Tragia involucrate, Trigonella foenusgraecum and Vigna unguiculata.

The nutrient composition of these vegetable plants varies in which most of the plants are regularly used by different communities of Northern Kerala. Villagers and NGO's are cultivating these leafy 
greens for their daily hood. Moreover, school and college students are making such vegetable garden through National Service Scheme (NSS) and National Cadet Corps (NCC) programmes. Out of the listed vegetables, the Amarathus species are the most commonly used leafy vegetable exhibiting higher fibre, protein and vitamin $\mathrm{C}$ content. Cassia tora species also has the same content. Different type of macronutrients like phosphorus, calcium, potassium, magnesium and micronutrients like zinc, iron, copper and manganese were also identified in most of these wildly growing leafy vegetables. These leafy vegetables are well adapted to northern Kerala's local climatic conditions, and most of them are growing as shade tolerant and grown as wild plants without proper care. These vegetables are domesticated by a standardized agronomic practices like the naturally selected saplings or propagules.

Table: List of common leafy greens of Northern Kerala

\begin{tabular}{|c|c|c|c|}
\hline SI. No. & Scientific name & Common name & Local name \\
\hline 1 & Aerva lanata & Mountain knot grass & Cheroola \\
\hline 2 & Alternanthera sessilis & Sessile joyweed, dwarf copper leaf, Joyweed & Ponnanganni/Aksharacheera \\
\hline 3 & Amaranthus polygonoides & Tropical amaranth & Cherucheera \\
\hline 4 & Amaranthus spinosus & Prickly amaranth & Mullancheera \\
\hline 5 & Amaranthus viridis & Amaranthus & Chuvannacheera \\
\hline 6 & Amorphophallus commutatus & Dragon stalk yam & Kattuchena \\
\hline 7 & Amorphophallus paeoniifolius & Elephant yam & Chena ila \\
\hline 8 & Artocarpus heterophyllus & Jack fruit & Plavu \\
\hline 9 & Asystasia gangetica & Tropical violet & Thuppalampotti, Velipadakkam \\
\hline 10 & Bacopa monnieri & Water hyssop & Brahmi \\
\hline 11 & Basella alba & Malabar spinach & Vallicheera/Vasalacheera \\
\hline 12 & Benincasa pruriens $f$. hispida & Ash gourd, white pumpkin & Kumbalamila \\
\hline 13 & Beta vulgaris & Beetroot & Beetroot \\
\hline 14 & Boerhavia diffusa & Red hogweed & Thazhuthama \\
\hline 15 & Cardiospermum halicacabum & Balloon vine or love in a puff & Uzhinja \\
\hline 16 & Centella asiatica & Indian pennywort & Kudangal/Muthil \\
\hline 17 & Chenopodium album & $\begin{array}{l}\text { Bathua, fat hen, lamb's quarters, white } \\
\text { goosefoot }\end{array}$ & $\begin{array}{l}\text { Parippuchira, vastucheera, } \\
\text { katuayamodakam }\end{array}$ \\
\hline 18 & Cichorium intybus & Chicory, Blue sailors, Succory, Coffeeweed & Chikkari \\
\hline 19 & Cissus quadrangularis & Veldt grape & ChangalamParanda \\
\hline 20 & Clerodendrum serratum & Blue fountain bush & Cherutekku \\
\hline 21 & Cnidoscolus aconitifolius & Tree spinach & Chayamansa \\
\hline 22 & Coccinia grandis & Ivy gourd & Kovakkaila \\
\hline 23 & Colocasia esculenta & Colocasia & $\begin{array}{l}\text { Kaattuchembu, madantha, } \\
\text { thaalu, maanam }\end{array}$ \\
\hline 24 & Commelina benghalensis & Bengal dayflower & Adukkavettila, Kaanavazha \\
\hline 25 & Cucurbita moschata & Pumpkin & Mathanila \\
\hline 26 & Cyanotis cristata & Crested cat ears & Vettilakettu \\
\hline 27 & Daucus carota subsp. sativus & Carrot & Carrot \\
\hline 28 & Diplazium esculentum & Vegetable fern & Churuli \\
\hline 29 & Eclipta alba & False daisy & Kaiyyonni \\
\hline
\end{tabular}




\begin{tabular}{|c|c|c|c|}
\hline 30 & Eryngium foetidum & Culantro & African malli \\
\hline 31 & Erythrina variegata & Indian coral tree, Tiger claw & Kalyana Murikku, Mullumurikku \\
\hline 32 & Hibiscus sabdariffa & Roselle & Mathipuli \\
\hline 33 & Ipomea aquatica & Water spinach & Vayalcheera \\
\hline 34 & Ipomoea batatas & Sweet potato & Madhurakizhangila \\
\hline 35 & Leucas zeylanica & Ceylon leuca & Thumba \\
\hline 36 & Limnophila repens & Creeping marsh weed & Maanganaari \\
\hline 37 & Momordica charantia & Bitter gourd & Kaipakka/Pavakkaila \\
\hline 38 & Moringa oleifera & Moringa & Muringaila \\
\hline 39 & Murraya koenigii & Indian curry leaf & Kariveppila \\
\hline 40 & Oxalis corniculata & Wood sorrel & Puliyarila \\
\hline 41 & Passiflora edulis & Passion fruit & Passion fruit \\
\hline 42 & Peperomia pellucida & Shiny bush & Mashithand \\
\hline 43 & Piper betel & Betel & Vettila \\
\hline 44 & Pisonia alba & Lettuce tree & Sauhridacheera \\
\hline 45 & Plectranthus amboinicus & Cuban oregano, Indian borage & Panikoorka \\
\hline 46 & Portulaca oleracea & Purslane & PachaIla \\
\hline 47 & Pouzolzia zeylanica & Graceful pouzolz's bush & Kallurukki, neicheera \\
\hline 48 & Premnaserr atifolia & & Munja \\
\hline 49 & Raphanus sativus & Radish & Mullangiila \\
\hline 50 & Sauropus androgynus & Sweet leaf bush/Star gooseberry/Multi & $\begin{array}{l}\text { Madhuracheera/ vitamin plant } \\
\text { Cucurumanicheera }\end{array}$ \\
\hline 51 & Senna tora & Sickle senna & Thakara \\
\hline 52 & Sesbania grandiflora & Agati & Agathicheera \\
\hline 53 & Solanum nigrum & Black nightshade & Manathakkali/Mulaku-thakkali \\
\hline 54 & Solanum trilobatum & Purple fruited pea eggplant & Putharichunda \\
\hline 55 & Talinum fruticosum & Ceylon spinach & Sambarcheera \\
\hline 56 & Tamarindus indica & Tamarind tree & Puliila \\
\hline 57 & Tinospor acordifolia & $\begin{array}{l}\text { Gulbel, Indian tinospora, heart-leaved } \\
\text { moonseed }\end{array}$ & $\begin{array}{l}\text { Amritavalli, chittamruth, } \\
\text { peyyamrutham }\end{array}$ \\
\hline 58 & Tragia involucrata & Climbing nettle & $\begin{array}{l}\text { Choriyanam/ aanathumba/ } \\
\text { Kodithoova }\end{array}$ \\
\hline 59 & Trigonella foenum-graecum & Fenugreek & Uluvaila \\
\hline 60 & Vigna unguiculata & Yard long beans & Payaruila \\
\hline
\end{tabular}




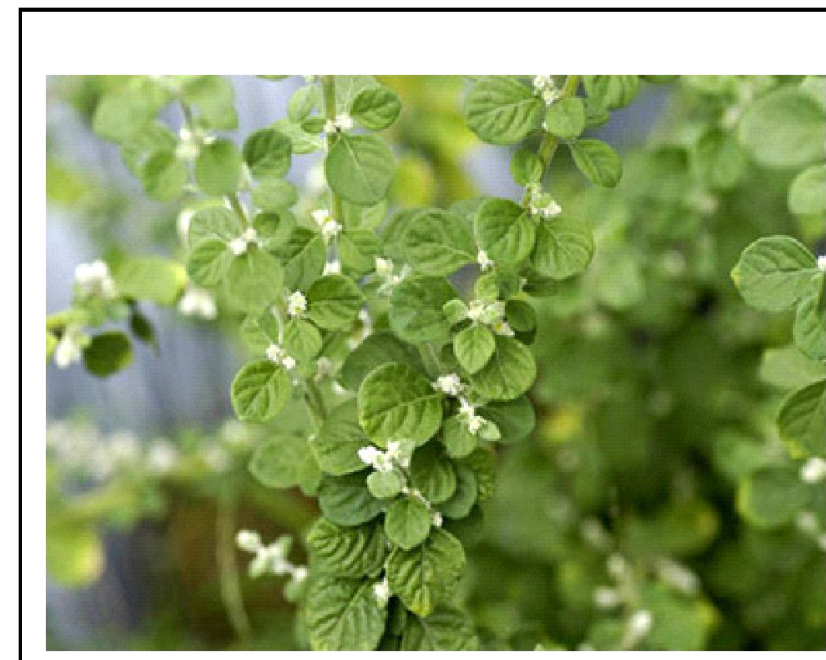

Aerva lanata

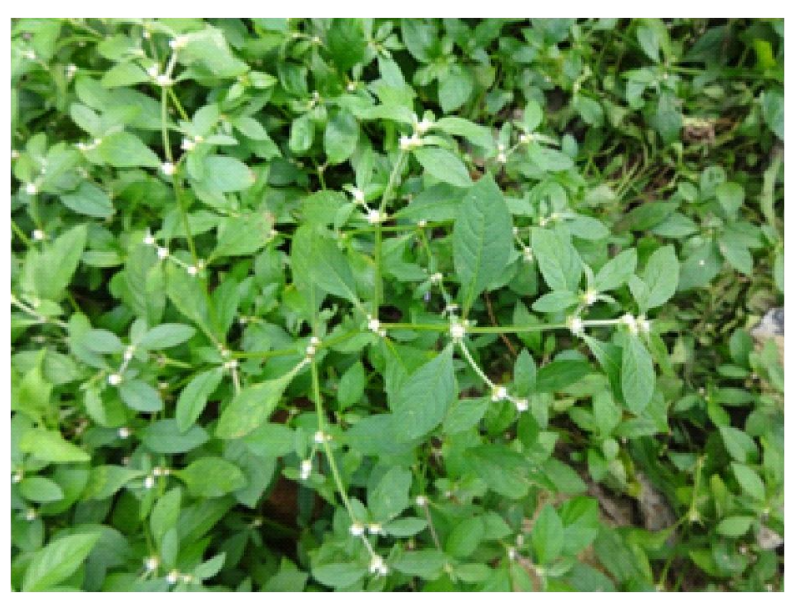

Alternanthera sessilis

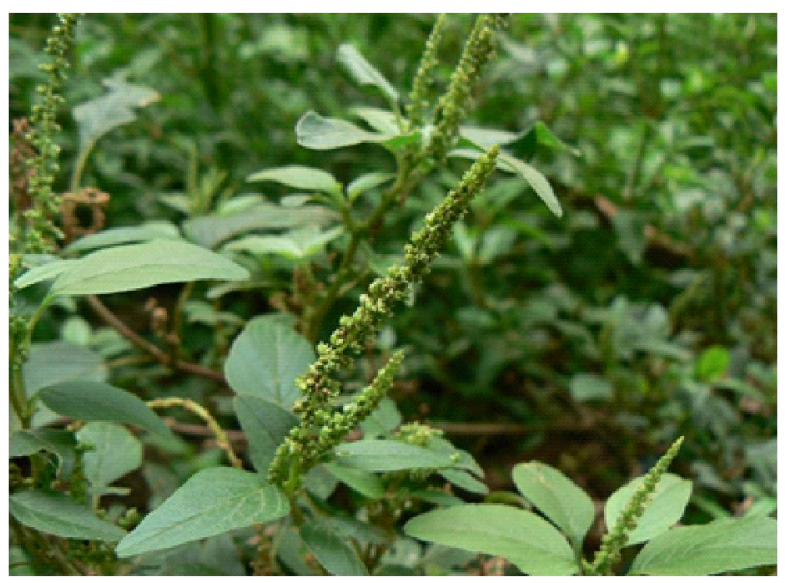

Amaranthus spinosus

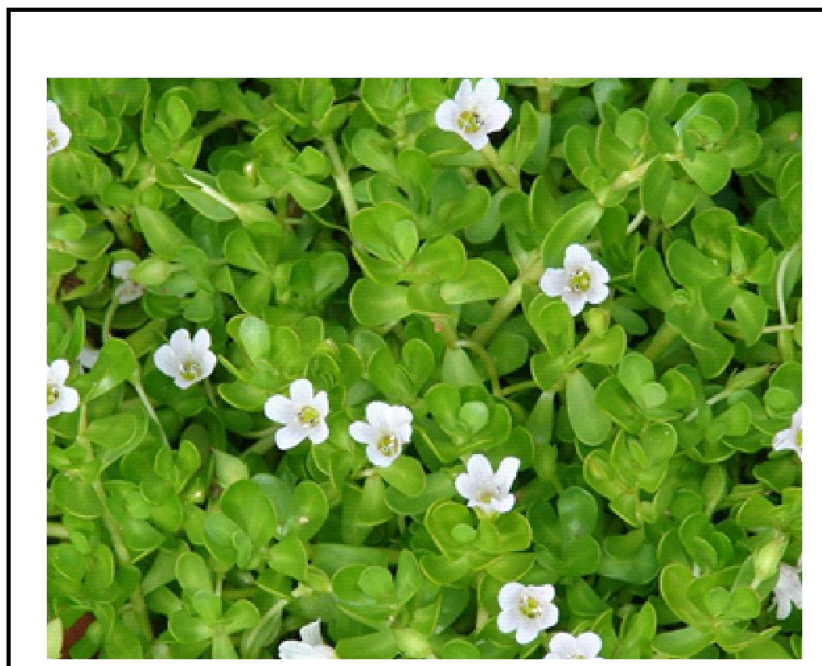

Bacopa monnieri

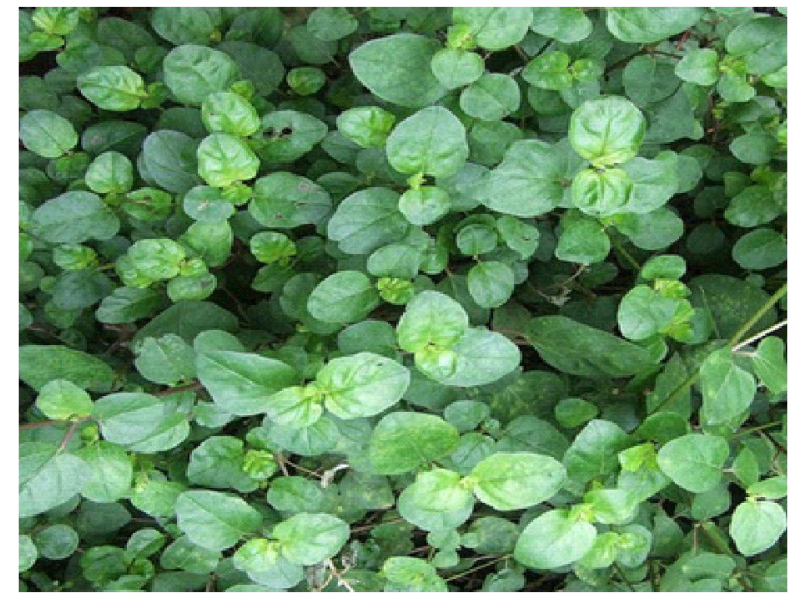

Boerhavia diffusa

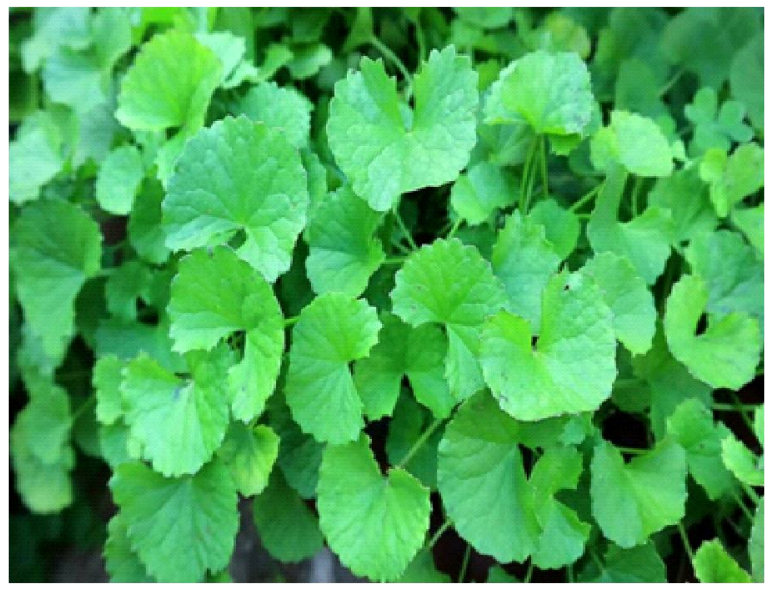

Centella asiatica 


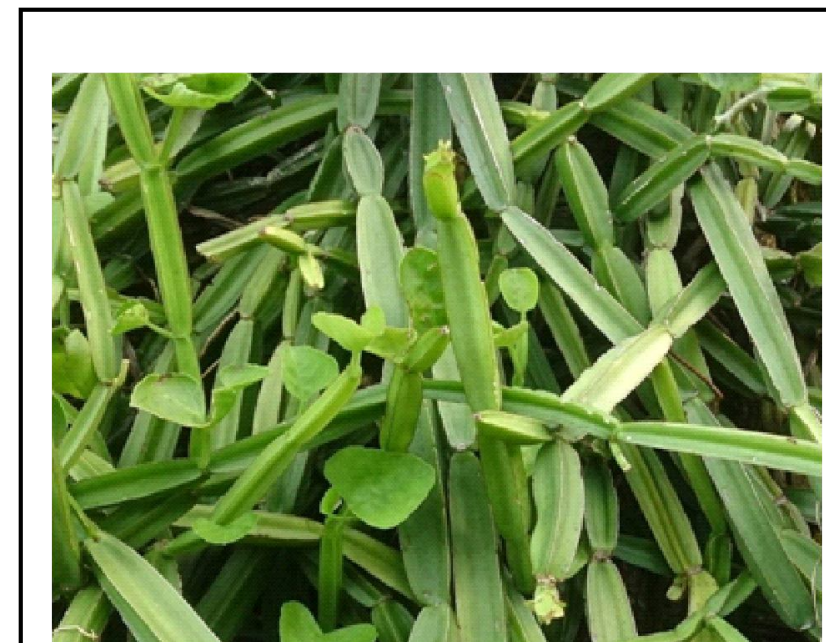

Cissus quadrangularis

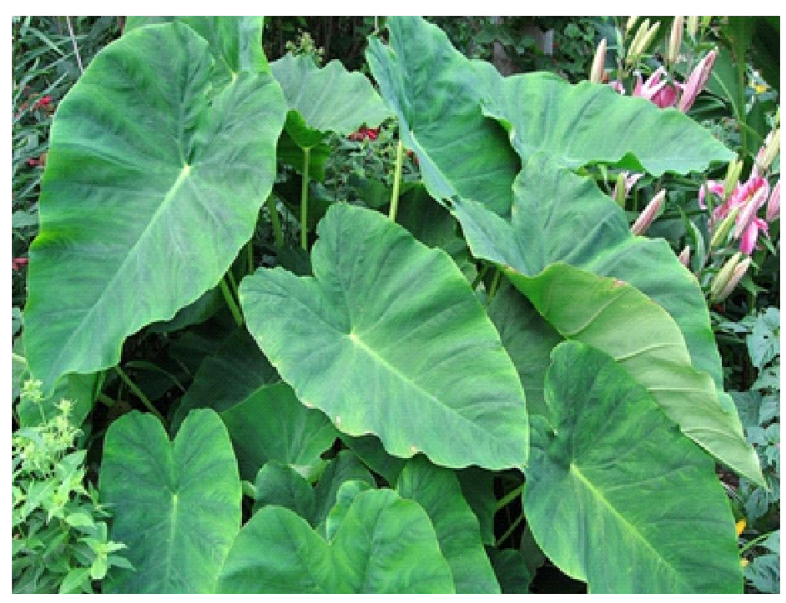

Colocasia esculenta

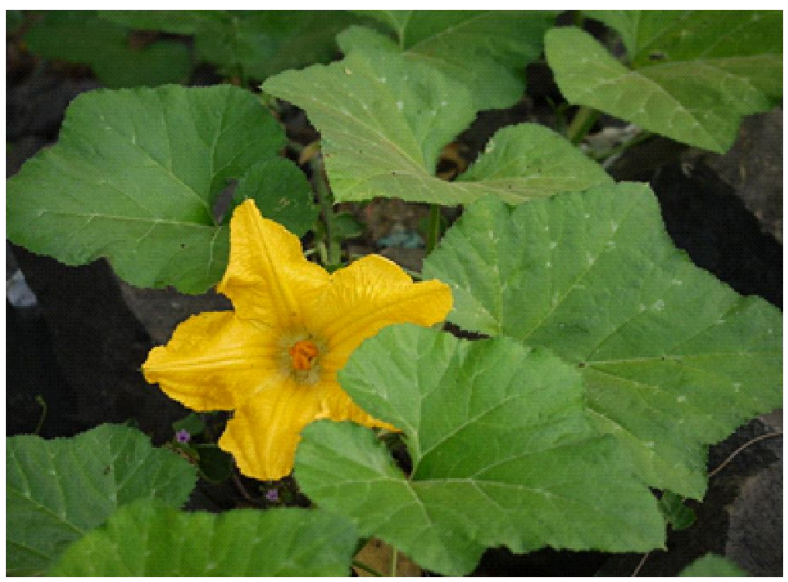

Cucurbita moschata

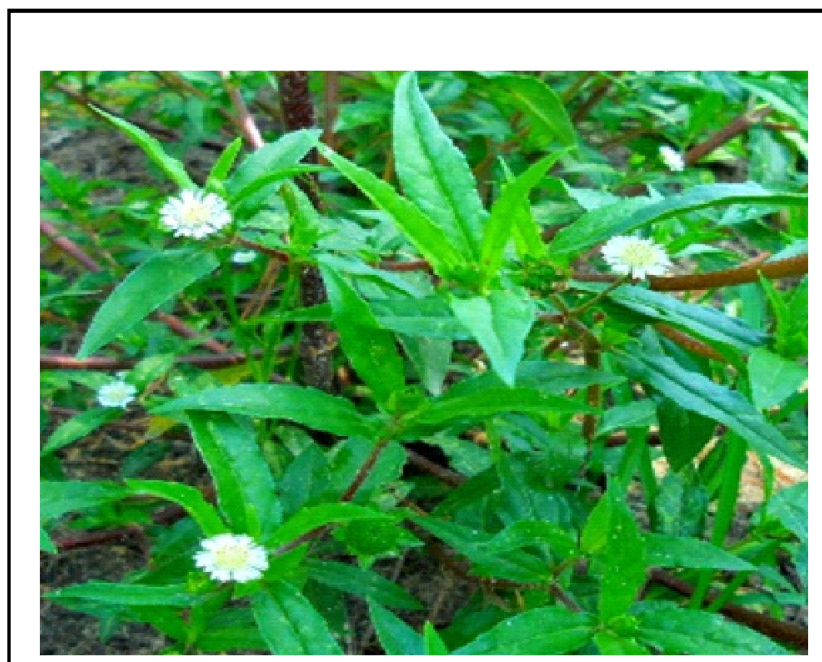

Eclipta alba

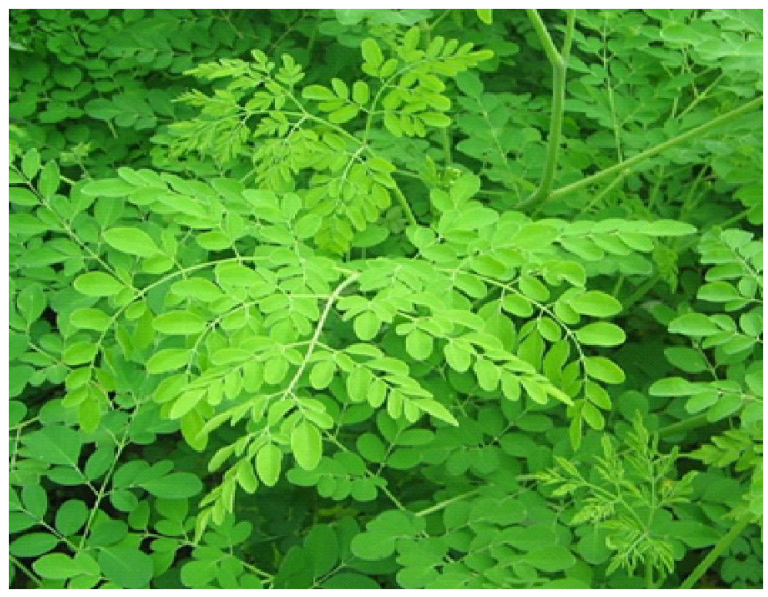

Moringa oleifera

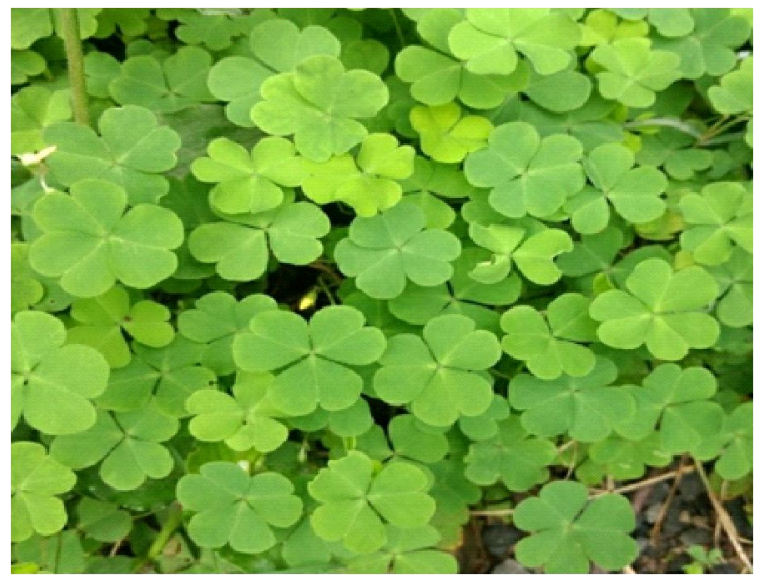

Oxalis corniculata 


\subsection{Nutrient diversity of leafy greens/vegetables}

\subsubsection{Proteins}

Metabolic activities are regulated by the influence of proteins, which play a critical role in the cellular functions of living organisms. Daily diets of the consumer's body are greatly influencing proteins. The most important sources of proteins are green leafy vegetables. These proteins have a great ability to synthesize and accumulate amino acids with the help of sunlight, oxygen, water and nitrogen (Radek and Savage, 2008). About 50\% of total leaf cell protein is dominated by ribulose-1,5-bisphosphate carboxylase/oxygenase (RUBISCO), which can be found in leaf chloroplasts. It plays a vital role in the fixation of atmospheric carbon during photosynthesis. RUBISCO is a similar protein found in all green leafy vegetables with few changes in amino acid groups from species to species. Many shreds of evidence are found that green leafy vegetables as recent evidence showed that green leafy vegetables such as broccoli (Brassica oleracea var. Italic), duckweed (Lemna perpusilla) and spinach (Spinacia oleracea) provide all the essential amino acids that meet the FAO nutrition standards.

The amount of protein content present in the leafy vegetables can vary with farming practices and governing environmental conditions (Ravindran et al., 1999; Yadav and Sehgal, 2003; Colonna et al., 2016; Da-Silva Das et al., 2017; Dagostin, 2007; Da-Silva Dias et al., 2017; Wu et al., 2020). The bioavailability of protein in different leafy vegetables is typically prejudiced by thermal processing, which inactivates heat-labile antinutritional factors such as protease inhibitors, lectins, thiaminases, and goitrogens but enhances digestibility of proteins and starch (Nath et al., 2004; Fausyi, 2005; Dias, 2012; Frasca and Blomberg, 2020).

\subsubsection{Dietary fiber}

Green leafy vegetables have been traditionally recognized as good sources of dietary fiber (Oboh, 2005). Leafy vegetables such as fenugreek (Trigonella foenum-graecum), coriander (Coriandrum sativum), hibiscus (Hibiscus cannabinus), spinach (Spinacia oleracea), basella (Basella rubra) and cabbage (Brassica oleracea) are good sources of soluble dietary fibre content. Feeding higher levels of vegetable fiber caused reduced risk of cardiovascular diseases and possibly colon cancer (Paks et al., 2008). It will help reduce constipation, diabetes, diverticulosis, and obesity due to the consumption of vegetables (Freudenberg and Weingebs, 1962; Fann and Kaneene, 1993; Fasuyi, 2005; Raju et al., 2007).

\subsubsection{Vitamins}

Different vitamins are present in the green leafy vegetables, which are abundant sources for $\beta$-carotene. In leaves, vitamin $A$ is present in the form of provitamin A carotenoids such as $\beta$-carotene (ca. 25$30 \%), \alpha$-carotene, $\gamma$-carotene, $\beta$-cryptoxanthin, and non-provitamin A carotenoids lutein (ca. 45\%), violaxanthin (ca.15\%) and neoxanthin (ca.15\%), the content of vitamin $\mathrm{A}$ is expressed in retinol equivalents (RE) with one (1) RE being equivalent to $6 \mu \mathrm{g}$ of $\beta$-carotene and 12 $\mu \mathrm{g}$ of the other pro-vitamin carotenoids (Freudengberg and Weinges, 1962). Continuous consumption of green leafy vegetables that are widely obtainable in emerging countries help in combating prevailing vitamin A shortage in regions where pharmaceutical additions and vitamin A fortified foods are imperfect (Freudenberg and Weinges, 1962; Kamalu, 1993; Grusak and Penna, 1995; Gopalan et al., 2000; Gibson et al., 2006; Kalogeropoulos et al., 2010; Dos-Santos et al., 2016; Gombart et al., 2020).

\subsubsection{Minerals}

WHO (1996) stated that the overall malnutrition must no longer be considered without reference to micronutrient status, as the two are inextricably linked. Green leafy vegetables are good sources of mineral nutrients. For instance, phosphorus (469 mg/100 g), magnesium $(827 \mathrm{mg} / 100 \mathrm{~g})$, whereas duckweed is high in zinc (15 $\mathrm{mg} / 100 \mathrm{~g}$ ). However, soy seed also has a considerable amount of iron $(28.4 \mathrm{mg} / 100 \mathrm{~g})$, calcium (195 mg/100 g), magnesium (407 mg/ $100 \mathrm{~g}$ ), sodium (827 mg/100 g), potassium (2387 mg/100 g), and zinc $(3.7 \mathrm{mg} / 100 \mathrm{~g})$ spinach has the highest amount of calcium $(1036 \mathrm{mg} / 100 \mathrm{~g})$, when compared to all the seeds but comparatively higher in the leafy vegetables (Harland and Oberleas, 1987; Kala and Prakash, 2004; Gibson et al., 2006; Gupta et al., 2015; Gombart et al., 2020)

\section{Conclusion}

Nutrion role in immune system is very important in present scenario. Immune system is considred as the prime defence mechanism against the infection in the body. Proper planning and dieting is indispensable in tracking the diseases. Macro and micronutrients are playing very important role in immunity process. COVID-19 pandemic is one of the most important viral diseases, in which people with low immunity are more prone in this world. To boost immunity, plant content-based food would play an important role by promoting beneficial bacteria in the human body. Vitamins like C, D, and E are found to be important aspects for increasing immunity. Vegetables and fruits are playing a very important role in boosting immunity. Green leafy vegetables are typically considered inexpensive sources of food for vitamins and micronutrients supplementation to contest nutrient deficiencies. It is also used as herbal and medicinal plants in numerous cultural and traditional settings for many different illnesses. Thermal dispensation of leafy vegetables through roasting, cooking, and lightening before feeding help in reducing the level of anti-nutrients. Fruits like passiflora, jackfruit, papaya, guava, and oranges are rich in vitamin C. At the same time, vegetables like beetroots, spinach, and cauliflower are known to be quite rich in vitamin $\mathrm{C}$ and are decent for immunity. Leafy vegetables like Amaranth, Boerhavia, Moringa, Agathi, Spinach, Cabbage even kale, and broccoli are considered the immunity boosting plants that rapidly improve the immune system.

Moreover, some herb mixture is also known to play a crucial role in the prevention COVID-19. Green leafy vegetables deliver vital nutrients obligatory for human health and happiness. Future aspects of this account for more research which is needed significantly on physical behaviors or exercises and their role in immunity related issues, thus preventing COVID-19 aspects. Green foods are energetic against original coronavirus by refining the immunity of all aged groups. These comprise vitamins, essential fatty acids, minerals, amino acids, and dietary fibre. It also has important socioeconomic welfares. Farmers in the tropics and subtropics, mostly women, grow and harvest green leafy vegetables to supplement domestic income. Research is important to identify and explore the rich potential of green leaves having traditional knowledge use as medicine and food. Role of each elements and biomolecules present in the leafy greens are related nutrion are important and which are helping to maintain and strengthen the defence mechanism of the body to fight against different pandemic especially COVID-19. More investigation is needed to identify the different diversities and 
probabilities of accommodating precious agronomic en actment that will decrease the in attention and effect of antinutritional factors in leafy vegetables and improve their nutritional value.

\section{Conflict of interest}

The authors declare that there are no conflicts of interest relevant to this article.

\section{References}

Aguilar, D.M.and Grusak, M,A.(2017). Minerals, vitamin C, phenolics, flavonoids, and antioxidant activity of Amaranthus leafy vegetables. Journal of Food Composition and Analysis, 58:33-39.

Ahern, P.P. and Maloy, K.J. (2020). Understanding immune-microbiota interactions in the intestine. Immunology, 159:4-14.

Aletor, O.; Oshodi, A. and Ipinmoroti, K. (2002). Chemical composition of common leafy vegetables and functional properties of their leaf protein concentrates. Food Chemistry, 78(1):63-68.

Alexander, J.; Benford, D. and Cockburn, A. (2008). Nitrate in vegetables scientific opinion of the panel on contaminants in the food chain. E.F.S.A. J., 689:1-79.

Bacala, R. and Barthet, V. (2007). Development of extraction and gas chromatography analytical methodology for cyanogenic glycosides in flaxseed (Linumusitatis simum). J.A.O.A.C. Int., 90(1):153-161.

Baudoin, W.O. and Fresco, O. (2002). Food and nutrition security towards human security. I.C.V. Souvenir Paper, Italy, pp:1-19.

Britton, G. (1996). Carotenoids. In: Hendry G.A.F., editors. Natural food colorants, Springer, U.S.A., pp:197-243.

Calder, C. (2020). Nutrition, immunity and COVID-1, B.M.J. Nutrition, Prevention and Health, pp:74-92.

Casanova, J.A.; Gross, L.K. and Mc-Mullen, S.E. (2006). Use of griess reagent containing vanadium (III) for post-column derivatization and simultaneous determination of nitrite and nitrate in baby food. $\mathbf{J}$. A.O.A.C. Int., 89(2):447-451.

Chai, W. and Liebman, M. (2005). Oxalate content of legumes, nuts, and grain-based flours. Journal of Food Composition and Analysis, 18(7):723-729.

Champ, M.M. (2002). Non-nutrient bioactive substances of pulses. Br. J. Nutr., 88(3):307-319.

Chen, Y.; Liu, Q. and Guo, D. (2020). Emerging coronaviruses: Genome structure, replication, and pathogenesis. J. Med. Virol., 92:418-23.

Colonna, E.; Rouphael, Y. and Barbieri, G. (2016). Nutritional quality of tenleafy vegetables harvested at two light intensities. Food Chem., 199:702-710.

Dagostin, J.L.A. (2017). Use of blanching to reduce anti-nutrients, pesticides, and microorganisms. In: Richter Reis F. editor. New perspectives on food blanching, Springer, U.S.A., pp:61-94.

Da-Silva Dias, Jarlos, and Imai, S. (2017). Vegetables consumption and its benefits on diabetes. J. Nutri. Ther., 6(1):1-10.

Dias, J.S. (2012). Major classes of phytonutriceuticals in vegetables and health benefits: A review. J. Nutri. Ther., 1(1):31-62.

Fann, C.S. and Kaneene, J.B. (1993). The effects of nitrate, nitrite and Nnitroso compounds on human health: A review. Vet Hum Toxicol., 35(6):521-538.

Fasuyi, A.O. (2005). Nutrient composition and processing effects on cassava leaf (Manihot Esculenta Crantz) antinutrients. Pakistan J. Nutri., 4(1):37-42.
Frasca, D. and Blomberg, B.B. (2020). The impact of obesity and metabolic syndrome on vaccination success. Interdiscip. Top. Gerontol. Geriatr., 43:86-97.

Freudenberg, K. and Weinges, K. (1962). Catechins and flavonoid tannins. The Chemistry of Flavonoid Compounds, pp:197-216.

Gibson, R.S.; Perlas, L. and Hotz, C. (2006). Improving the bioavailability of nutrients in plant foods at the household level. Proc. Nutr. Soc., 65(2): $160-168$

Gombart, A.F.; Pierre, A. and Maggini, S. (2020). A review of micronutrients and the immune System. Working in harmony to reduce the risk of infection. Nutrients, 12:E236.

Gopalan, C.; Ramasastri, B. and Balasubramanian, S. (2000). Proximate principles: Common foods. Nutritive Value of Indian Foods (Revised and Updated Edition). Hyderabad, India: National Institute of Nutrition, I.C.M.R., India, pp:53-55.

Grusak, M.A. and Penna, D. (1995). Improving the nutrient composition of plants to enhance human nutrition and health. Annu. Rev. Plant Physiol. Plant Mol. Biol., 50(1):133-161.

Gupta, R. and Haslam, E. (1980). Vegetable tannins: Structure and biosynthesis. Paper presented at the Polyphenols in Cereals and Legumes: Proceedings of a Symposium, U.K.

Gupta, R.K.; Gangoliya, S.S. and Singh, N.K. (2015). Reduction of phytic acid and enhancement of bioavailable micronutrients in food grains. J. Food Sci. Technol., 52(2):676-684.

Harland, B.F. and Oberleas, D. (1987). Phytate in foods. Energy. Nutrition of women, Karger Publishers, Japan, pp:235-259.

Jenkins, D.J.; Kendall, C.W. and Popovich, D.G. (2001). Effect of a very-highfiber vegetable, fruit, and nut diet on serum lipids and Colonic function. Metabolism, 50(4):494-503.

Kala, A. and Prakash, J. (2004). Nutrient composition and sensory profile of differently cooked green leafy vegetables. International Journal of Food Properties, 7(3):659-669.

Kalogeropoulos, N.; Chiou, A. and Ioannou, M. (2010). Nutritional evaluation and bioactive microconstituents (phytosterols, tocopherols, polyphenols, triterpenic acids) in cooked dry legumes usually consumed in the Mediterranean countries. Food Chemistry, 121(3):682-690.

Kamalu, B.P. (1993). Cassava (Manihot esculenta crantz) in the etiology of kwashiorkor. Nutrition Res. Reviews, 6(1):121-135.

Kumari, M.; Gupta, S. and Lakshmi, A.J. (2004). Iron bioavailability in green leafy vegetables cooked in different utensils. Food Chemistry, 86(2):217-222.

Leung, C. (2020). Clinical features of deaths in the novel coronavirus epidemic in China. Rev. Med, Virol., 30:2103-2118.

Liang, T. (2020). Handbook of COVID-19 prevention and treatment, Available: https://covid19.alnap.org/help-library/handbook-ofcovid19-prevention-and-treatment.

Louisce, O. and Wilfried, O. (2004). Food and nutrition security towards Human security, food security and vegetables: A global perspective, P.N. Agricultural Science Foundation, Bangalore, India, pp:7-42.

Mepba, H.; Eboh, L. and Banigo, D. (2007). Effects of processing treatments on the nutritive composition and consumer acceptance of some Nigerian edible leafy vegetables. African Journal of Food, Agriculture, Nutrition and Development, 7(1):72-89.

Nath, P. Gaddagimath P.B. and Dutta, O. (2004). Food and nutrition security and vegetables: A Global Perspective. PremNath Agricultural Science Foundation, India, pp:1-412. 
Oboh, G. (2005). Effect of blanching on the antioxidant properties of some tropical green leafy vegetables. LWT-Food Science and Technology, 38(5):513-517.

Odhav, B.; Beekrum, S. and Akula, U. (2007). Preliminary assessment of nutritional value of traditional leafy vegetables in Kwa Zulu-Natal, South Africa. J. Food Compos. and Analysis, 20(5):430-435.

Onyesom, I. and Okoh, P. (2006). Quantitative analysis of nitrate and nitrite contents in vegetables commonly consumed in delta state, Nigeria. Br. J. Nutr., 96(5):902-905.

Parks, S; Huett, D. and Campbell, L. (2008). Nitrate and nitrite in Australian leafy vegetables. Austra. J. Agricul. Rese., 59(7):632-638.

Price, M.L. and Butler, L.G. (1978). Rapid visual estimation and spectro photometric determination of tannin content of sorghum grain. J. Agric. Food Chem., 25(6):1268-1273.

Radek, M. and Savage, G. (2008). Oxalates in some Indian green leafy vegetables. Int. J. Food Sci. Nutr., 59(3):246-260.

Raju, M.; Varakumar, S. and Lakshminarayana, R. (2007). Carotenoid composition and vitamin A activity of medicinally important green leafy vegetables. Food Chemistry, 101(4):1598-1605.

Ramulu, P. and Rao, P.U. (2003). Total insoluble and soluble dietary fiber contents of Indian fruits. J. Food Comp. Analy., 16(6):677-685.

Ravindran, V.; Selle, P. and Bryden, W. (1999). Effects of phytase supplementation, individually and in combination, with glycanase, on the nutritive value of wheat and barley. Poult. Sci., 78(11):15881595 .

Reddy, N.R. and Sathe, K. (2001). Occurrence, distribution, content, and dietary intake of phytate. 1st edition. Food Phytates. U.S.A.: C.R.C Press, pp: 1-280.

Sallard, E.; Lescure, F.X. and Yazdanpanah, Y. (2020). C-20-15 discovery French Steering Committee (2020) type 1 interferons as a potential treatment against COVID-19. Antiviral Res., 178:104791.

Santos, J.; Mendiola, J, Oliveira, M, (2012). Sequential determination of fatand water, soluble vitamins in green leafy vegetables during storage. J. Chromatogr. A., 1261:179-188.
Shukla, P.; Kumar, R. and Raib, A.K. (2016). Detection of minerals in green leafy vegetables using laser induced breakdown spectroscopy. J. Appl. Spectroscopy, 83(5):872-877.

Sušin, J.; Kmecl, V. and Gregorèiè, A. (2006). A survey of nitrate and nitrite content of fruit and vegetables grown in slovenia during Food Addit. Contam., 23(4):385-390.

Tamme,T.; Reinik, M. and Roasto, M. (2010). Nitrate in leafy vegetables, culinary herbs, and cucumber grown under cover in estonia: Content and intake. Food Addit. Contam. Part B Surveill., 3(2):108-113.

Torres, F.; Parra, P.A. and Méndez, R.V. (2014). Natural folates from biofortified tomato and synthetic 5-methyl-tetrahydrofolate display equivalent bioavailability in a murine model. Plant Foods Hum. Nutr., 69(1): 57-64.

Uusiku, N.P.; Oelofse, A. and Duodu, K.G. (2010). Nutritional value of leafy vegetables of sub-Saharan Africa and their potential contribution to human health:A review. J. of Food Comp. and Analysis, 23(6):499509 .

World Health Organization, International Atomic Energy Agency and Food and Agriculture Organization of the United Nations. (1996). Trace elements in human nutrition and health. World Health Organization. https:/ /apps.who.int/iris/handle/10665/37931.

World Health Organization. (2020). Coronavirus disease 2019 (COVID-19): situation report, 30. World Health Organization. https://apps. who. int/iris/handle/10665/331119.

Wu, D.; Wu, T. Liu, Q. (2020). The SARS-CoV-2 outbreak: What we know. Int. J. Infect. Dis., 94:44-48.

Yadav, S.K. and Sehgal, S. (2003). Effect of domestic processing and cooking on selected anti nutrient contents of some green leafy vegetables. Plant Foods for Human Nutri., 58(3):1-11.

Yang, F.; Zhang, C. Liu,Q. (2015). Ca2 - selective electrode: A simple method to measure the phytase - aided release of bound calcium in soymilk. J. of Food Comp. Analysis, 39:43-47. 